\title{
Metal concentrations and mycorrhizal status of plants colonizing copper mine tailings: potential for revegetation
}

\author{
CHEN Baodong' ${ }^{1}$, TANG Xiangyu' ${ }^{1}$, ZHU Yongguan ${ }^{1} \&$ CHRISTIE Peter ${ }^{2}$ \\ 1. Research Center for Eco-Environmental Sciences, Chinese Academy of Sciences, Beijing 100085, China; \\ 2. Department of Agricultural and Environmental Science, The Queen's University of Belfast, Newforge Lane, Belfast BT9 5PX, Northern \\ Ireland, UK \\ Correspondence should be addressed to Zhu Yongguan (email: ygzhu@mail.rcees.ac.cn)
}

Received August 8, 2004

\begin{abstract}
A field survey of metal concentrations and mycorrhizal status of plants growing on copper mine tailings was conducted in Anhui Province, China. Available phosphorus and organic matter in the tailings were very low. High concentrations of $\mathrm{Pb}, \mathrm{Zn}, \mathrm{As}$ and $\mathrm{Cd}$ as well as $\mathrm{Cu}$ were observed on some sites. The dominant plants growing on mine tailings belonged to the families Gramineae and Compositae, and the most widely distributed plant species were Imperata cylindrica, Cynodon dactylon and Paspalum distichum. Coreopsis drummondii also grew well on the arid sites but not on wet sites. Very low or zero arbuscular mycorrhizal (AM) fungal colonization was observed in most of the plants, but extensive mycorrhizal colonization was recorded in the roots of $C$. drummondii and $C$. dactylon. Metal concentrations in plant tissues indicated that $I$. cylindrica and $P$. distichum utilized avoidance mechanisms to survive at high metal concentrations. The investigation suggests that remediation and revegetation of heavy metal contaminated sites might be facilitated by selection of tolerant plant species. Isolation of tolerant AM fungi may also be warranted.
\end{abstract}

Keywords: phytoremediation, revegetation, heavy metals, copper mine tailings, arbuscular mycorrhiza.

DOI: $10.1360 / 04 y c 0149$

In China, mining for metals is a large and important industry supporting economic development. The mining activities have brought not only economic prosperity, but also environmental problems. Abandoned mine tailings can result in severe pollution and have aesthetic impacts on the local environment. Mining and metal smelting have already become major sources of heavy metal contamination in soils and water bodies ${ }^{[1]}$. Effective measures need to be taken to remediate the land occupied by tailings so that risks to the environment can be controlled.

Among the remediation strategies available, physical or chemical methods can only temporarily stabilize the wastes, while revegetation is widely considered to be necessary for sustainable utilization of mining sites ${ }^{[2]}$. Revegetation may be achieved by direct seeding of plants. However, the metal tailings are mostly hostile environments for plant growth due to the presence of many growth limiting factors, particularly residual high levels of heavy metals, nutrient deficiencies and poor substrate structure ${ }^{[3]}$. These features result in many metal wastes being largely devoid of any natural vegetation, even many years after abandonment. It is therefore important to select appropriate plant species or ecotypes for revegetation purposes. In addition to the commercially available 
plants, it is most desirable to find native plants that may already be adapted to local soil and climatic conditions.

It is well known that mycorrhizal associations are ubiquitous in natural ecosystems, among which arbuscular mycorrhiza (AM) is the most widely distributed type. Mycorrhizal fungal diversity determines plant biodiversity, ecosystem variability and productivity ${ }^{[4,5]}$. Numerous studies have indicated that mycorrhizal colonization may increase plant tolerance to heavy metal contamination ${ }^{[6]}$. Application of AM fungi in phytoremediation has generally been accepted as a practical option. Mycorrhizal fungi appear to protect plants partially against the toxicity of heavy metals. On the other hand, the host plant may confer on the fungus a selective survival advantage at a contaminated site. This mutual benefit would make the mycorrhizal association superior to the application of single organisms, either non-mycorrhizal plants or free-living micro-organisms, for remediation purposes $^{[7]}$.

The significance of arbuscular mycorrhiza in plant uptake of metals from metal contaminated soils merits systematic studies ${ }^{[6]}$. The wide distribution of AM fungi on metal contaminated sites has shown general adaptation and tolerance of these symbionts to heavy metals ${ }^{[8-10]}$, and metal tolerant fungal strains have been isolated by several research groups ${ }^{[1-15]}$. Some recent studies have focused on the role of AM fungi in the stabilization, rather than the remediation, of metal polluted ecosystems ${ }^{[16-18]}$. However, there is little published information on field surveys of the mycorrhizal status of dominant plants growing on metal contaminated sites in China and the screening of metal tolerant AM fungal strains.

In this paper we report a field survey on metal concentrations in, and the mycorrhizal status of, plants colonizing copper mine tailings in Tongling City, Anhui Province, China. The aim of the present study was therefore to determine the feasibility of screening native metal tolerant plant species and isolating metal tolerant mycorrhizal fungi. It was hoped that the work would also help us understand the mechanisms of plant adaptation to the adverse environments of copper mine tailings and thus facilitate future revegetation programs.

\section{Materials and methods}

\subsection{Field survey and plant and soil sampling}

Tongling is located between $30^{\circ} 45^{\prime} 12^{\prime \prime} \mathrm{N}$ and $31^{\circ} 07^{\prime} 56^{\prime \prime} \mathrm{N}$ and $117^{\circ} 42^{\prime} 00^{\prime \prime} \mathrm{E}$ and $118^{\circ} 10^{\prime} 06^{\prime \prime} \mathrm{E}$. The city is well known for its large number of copper mines, and has a very long history of mining activities. Ecological restoration of the tailings is in its infancy in this region.

The field survey was conducted from 12 to 15 October 2002. According to the age of the tailings (years since abandonment) and vegetation types, four typical mine tailings were selected as sampling sites. Yangshulin tailings were abandoned 10 years before the study. Tailings located at Fenghuangshan and Tongguanshan have existed for more than 30 years, while Heishahe tailings have been in the riverbed for at least 40 years ${ }^{[19]}$.

The positions of the sampling sites were recorded using a Global Position System (GPS) and landscape and vegetation were recorded by digital camera (Fuji Finepix 6900 Zoom). Three tailing samples were collected at each sampling site. After removing the plant cover (if there was any), the tailings were sampled using a stainless steel shovel. About $2 \mathrm{~kg}$ of tailings packed in a plastic bag comprised one sample of tailings. Where plant communities were established on the tailings, the dominant plants were sampled and placed in paper bags. When possible, more than two (usually three) samples of each plant species were collected.

1.2 Preparation of soil and plant samples for chemical analysis

The tailings samples were taken to the laboratory and air dried. Large pieces of plant debris and other particles were removed. The tailings were firstly passed through a $2 \mathrm{~mm}$ sieve, and sub-samples $(\sim 200 \mathrm{~g})$ were then grinded and passed through a 1-mm sieve for the determination of $\mathrm{pH}$ and bioavailable nutrients; while sub-samples were passed through a $100-\mu \mathrm{m}$ 
sieve for determination of total nutrients and metals.

Tailings $\mathrm{pH}$ was measured with a $\mathrm{pH}$ meter using a tailings-to-water ratio of $1: 2.5(\mathrm{w} / \mathrm{v})$. Phosphorus was extracted with $0.5 \mathrm{~mol} \mathrm{~L}^{-1} \mathrm{NaHCO}_{3}(\mathrm{pH} 8.5)$ and determined colorimetrically by the vanadomolybdate method $^{[20,21]}$. Total $\mathrm{N}$ content and organic matter were determined by the Kjeldahl method and Tiurin method respectively. Total metal contents were measured by inductively coupled plasma-optical emission spectroscopy (ICP-OES) using a Perkin Elmer Optima $2000 \mathrm{DV}$ following $\mathrm{HNO}_{3}-\mathrm{HClO}_{4}$ digestion.

When a whole plant was collected as a sample, the shoots (or fronds) and roots were cut and processed as separate samples. All plant samples were carefully washed with tap water and then deionized water. Sub-samples of fresh roots were collected for assessment of mycorrhizal colonization. After oven drying at $70^{\circ} \mathrm{C}$ for $48 \mathrm{~h}$, sub-samples of shoots and roots were milled and digested by acid digestion using a mixture of $\mathrm{HNO}_{3}$ and $\mathrm{HClO}_{4}(4: 1 \mathrm{v} / \mathrm{v})$ at $225^{\circ} \mathrm{C}$, then subjected to multi-element analysis by ICP$\mathrm{OES}^{[22,23]}$. For evaluation of the plant tolerance or resistance to metal contaminations, shoot-to-root ratios of metal concentrations in plants and transfer factors (TF: metal concentration in plant shoots divided by metal concentration in tailings) were calculated.

Mycorrhizal colonization of roots was determined by clearing sub-samples of fresh roots in $10 \%$ (w/v) $\mathrm{KOH}$ and staining with Trypan blue using a modification of the procedure of Phillips and Hayman ${ }^{[24]}$ in which phenol was omitted from the solutions and $\mathrm{HCl}$ from the rinsing stage. Percentage of root length colonized was determined by the grid line intersect method $^{[25]}$. For the sake of brevity, when colonization rates in the same plant species were below $10 \%$, the status of mycorrhizal colonization was designated with a single asterisk ${ }^{*}$ ) to denote 'slight colonization'. Similarly, ${ }^{* *}$ indicates 'moderate colonization' (10\%-50\% of root length), and $* * *$ indicates 'extensive colonization' ( $>50 \%$ of root length). In cases where colonization was never observed, this is indicated by 'ND' (not detected).

\section{Results}

2.1 Physico-chemical characteristics of sampling sites

All tailing samples showed slight alkaline reaction with $\mathrm{pH}$ value ranging from 7.23 to 8.25 . Nitrogen, organic matter and available phosphorus (Olsen $P)$ in the tailings were generally low (table 1). In addition to high $\mathrm{Cu}$ concentrations found in all sampling sites, Heishahe tailings also showed contamination with $\mathrm{Pb}, \mathrm{Zn}, \mathrm{Cd}$ and $\mathrm{As}$. High concentrations of $\mathrm{Pb}$ and $\mathrm{Zn}$ were observed in material from Fenghuangshan, and As contamination was also found in Tongguanshan, Fenghuangshan and Yangshulin tailings (table 1).

2.2 Vegetation on mine tailings and mycorrhizal status of dominant plant species

At the Yangshulin site, planted poplar trees were surrounded by naturally occurring communities of Imperata cylindrica, Cynodon dactylon and Setaria viridis (table 2). Inula ensifolia and Erigeron acris were scattered along the walls of buildings. The Coreopsis drummondii community was very well developed and colonized a large area (fig. 1(a)). There were also some leguminous and cyperaceous plants such as Kummerowia striata and Cyperus rotundus.

Natural plant communities were virtually nonexistent at Fenghuangshan due to farming activities. Only some ferns grew along the edges of the fields. Plant communities on Tongguanshan were also species-poor, with the Imperata cylindrica the dominant plant species and Saussurea japoinca also present but less abundant (Fig. 1(c)). Miscanthus floridulus, a tall grass, occurred sporadically on the mountain but seldom formed a recognizable community.

At Heishahe (mainly riverbed) there were substantial stands of Cynodon dactylon and Paspalum distichum, and Phragmites communis also grew well in some wetland areas (fig. 1(d)).

In general, very low or even zero AM fungal colonization was observed in most of the plants examined (table 2), but extensive mycorrhizal coloniza- 
Table 1 Selected physico-chemical properties of mine tailings from different sampling sites (data presented are means of three samples)

\begin{tabular}{|c|c|c|c|c|c|c|c|c|c|c|}
\hline Sampling site & GPS data & $\mathrm{pH}$ & $\begin{array}{c}\text { Organic } \\
\text { matter }(\%)\end{array}$ & $\begin{array}{l}\text { Total N } \\
\left(\mathrm{g} \mathrm{kg}^{-1}\right)\end{array}$ & $\begin{array}{c}\text { Olsen-P } \\
\left(\mathrm{mg} \mathrm{kg}^{-1}\right)\end{array}$ & $\begin{array}{l}\text { Total } \mathrm{Cu} \\
\left(\mathrm{mg} \mathrm{kg}^{-1}\right)\end{array}$ & $\begin{array}{c}\text { Total } \mathrm{Zn} \\
\left(\mathrm{mg} \mathrm{kg}^{-1}\right)\end{array}$ & $\begin{array}{c}\text { Total Pb } \\
\left(\mathrm{mg} \mathrm{kg}^{-1}\right)\end{array}$ & $\begin{array}{l}\text { Total Cd } \\
\left(\mathrm{mg} \mathrm{kg}^{-1}\right)\end{array}$ & $\begin{array}{l}\text { Total As } \\
\left(\mathrm{mg} \mathrm{kg}^{-1}\right)\end{array}$ \\
\hline Yangshulin & $\begin{array}{l}\mathrm{N} 30^{\circ} 56.158^{\prime \prime} \\
\mathrm{E} 117^{\circ} 47.491^{\prime \prime}\end{array}$ & 8.25 & 1.63 & 0.31 & 3.73 & 799 & 95.2 & 39.8 & 1.23 & 38.2 \\
\hline Fenghuangshan & $\begin{array}{l}\mathrm{N} 30^{\circ} 52.558^{\prime \prime} \\
\mathrm{E} 118^{\circ} 00.308^{\prime \prime}\end{array}$ & 7.23 & 2.55 & 0.84 & 4.24 & 2805 & 801 & 223 & 2.79 & 42.8 \\
\hline Tongguanshan & $\begin{array}{l}\mathrm{N} 30^{\circ} 54.235^{\prime \prime} \\
\mathrm{E} 117^{\circ} 49.862^{\prime \prime}\end{array}$ & 7.96 & 1.09 & 1.27 & 4.24 & 414 & 71.4 & 48.5 & $N^{a)}$ & 121 \\
\hline Heishahe & $\begin{array}{l}\text { N30 } 56.196^{\prime \prime} \\
\text { E11 }\end{array}$ & 7.60 & 1.22 & 1.03 & 6.00 & 396 & 589 & 261 & 81.1 & 185 \\
\hline
\end{tabular}

a) ND, not detectable.

Table 2 Dominant plant species growing on copper mine tailings and colonization of plants by AM fungi

\begin{tabular}{|c|c|c|c|c|}
\hline Sampling site ${ }^{a)}$ & Dominant plant species & Family & Root colonization rates ${ }^{\mathrm{a})}$ & Replicates \\
\hline \multirow[t]{8}{*}{ Yangshulin } & Imperata cylindrica var. major (Nees) C.E. Hubb & Gramineae & * & 3 \\
\hline & Cynodon dactylon (L.) Per. & Gramineae & $* *$ & 3 \\
\hline & Setaria viridis (L.) Beauv. & Gramineae & $* *$ & 1 \\
\hline & Coreopsis drummondii Torr. Et Gray & Compositae & $* * *$ & 3 \\
\hline & Inula ensifolia $\mathrm{L}$. & Compositae & $*$ & 3 \\
\hline & Erigeron acris $\mathrm{L}$. & Compositae & * & 3 \\
\hline & Kummerowia striata (Thunb.) Schindl. & Leguminosae & $* *$ & 2 \\
\hline & Cyperus rotundus $\mathrm{L}$. & Cyperaceae & ND & 1 \\
\hline \multirow[t]{2}{*}{ Fenghuangshan } & Pteris cretica $\mathrm{L}$. & Pteridaceae & $*$ & 2 \\
\hline & Pteris vittata $\mathrm{L}$. & Pteridaceae & $* *$ & 1 \\
\hline \multirow[t]{3}{*}{ Tongguanshan } & Imperata cylindrica var. major (Nees) C.E. Hubb & Gramineae & ND & 3 \\
\hline & Miscanthus floridulus (Labill.) Warb & Gramineae & ND & 1 \\
\hline & Saussurea japoinca (Thunb.) Dc. & Compositae & ND & 2 \\
\hline \multirow[t]{3}{*}{ Heishahe } & Cynodon dactylon (L.) Per. & Gramineae & * & 3 \\
\hline & Paspalum distichum $\mathrm{L}$. & Gramineae & * & 3 \\
\hline & Phragmites communis Trin. & Gramineae & ND & 1 \\
\hline
\end{tabular}
colonized.

a) ND, not detected; *, slightly ( $<10 \%$ root length) colonized; ${ }^{* *}$, moderately ( $<0 \%$ root length) colonized; ${ }^{* * *}$, extensively ( $>50 \%$ root length)

tion was recorded in the roots of $C$. drummondii (fig. 1(b)), while C. dactylon growing at Yangshulin and the ferns at the Fenghuangshan site showed moderate root colonization.

\subsection{Plant phosphorus and metal concentrations}

$P$ concentrations in the plant samples were generally below $1 \mathrm{mg} \mathrm{g}^{-1}$, except for the fern samples from Fenghuangshan (Table 3). $\mathrm{Cu}$ concentrations varied among plant species (and plant components) and sampling sites, and all root samples showed higher $\mathrm{Cu}$ concentrations than corresponding shoot samples. The highest $\mathrm{Cu}$ concentration (> $800 \mathrm{mg} \mathrm{kg}^{-1}$ ) was observed in roots of Paspalum distichum from Heishahe. The same sample also contained high concentrations of $\mathrm{Zn}, \mathrm{Pb}, \mathrm{Cd}$ and $\mathrm{As}$ in accordance with the high metal concentrations found in the tailings at this site.

High concentrations of $\mathrm{Zn}$ occurred mostly in plant roots. However, Setaria viridis had $\mathrm{Zn}$ concentrations higher than $100 \mathrm{mg} \mathrm{kg}^{-1}$ in both shoots and roots. $\mathrm{Pb}$ concentrations above $20 \mathrm{mg} \mathrm{g}^{-1}$ were observed in shoots of Cynodon dactylon from Yangshulin and Imperata cylindrica from Tongguanshan, but corresponding root samples showed lower $\mathrm{Pb}$ concentrations. In contrast, Pteris cretica from Fenghuangshan accumulated much more $\mathrm{Pb}$ in the roots than in the shoots. $\mathrm{Pb}$ concentrations were generally below 10 $\mathrm{mg} \mathrm{kg}^{-1}$ in the other plant samples.

Consistent with the $\mathrm{Cd}$ and As concentrations in 


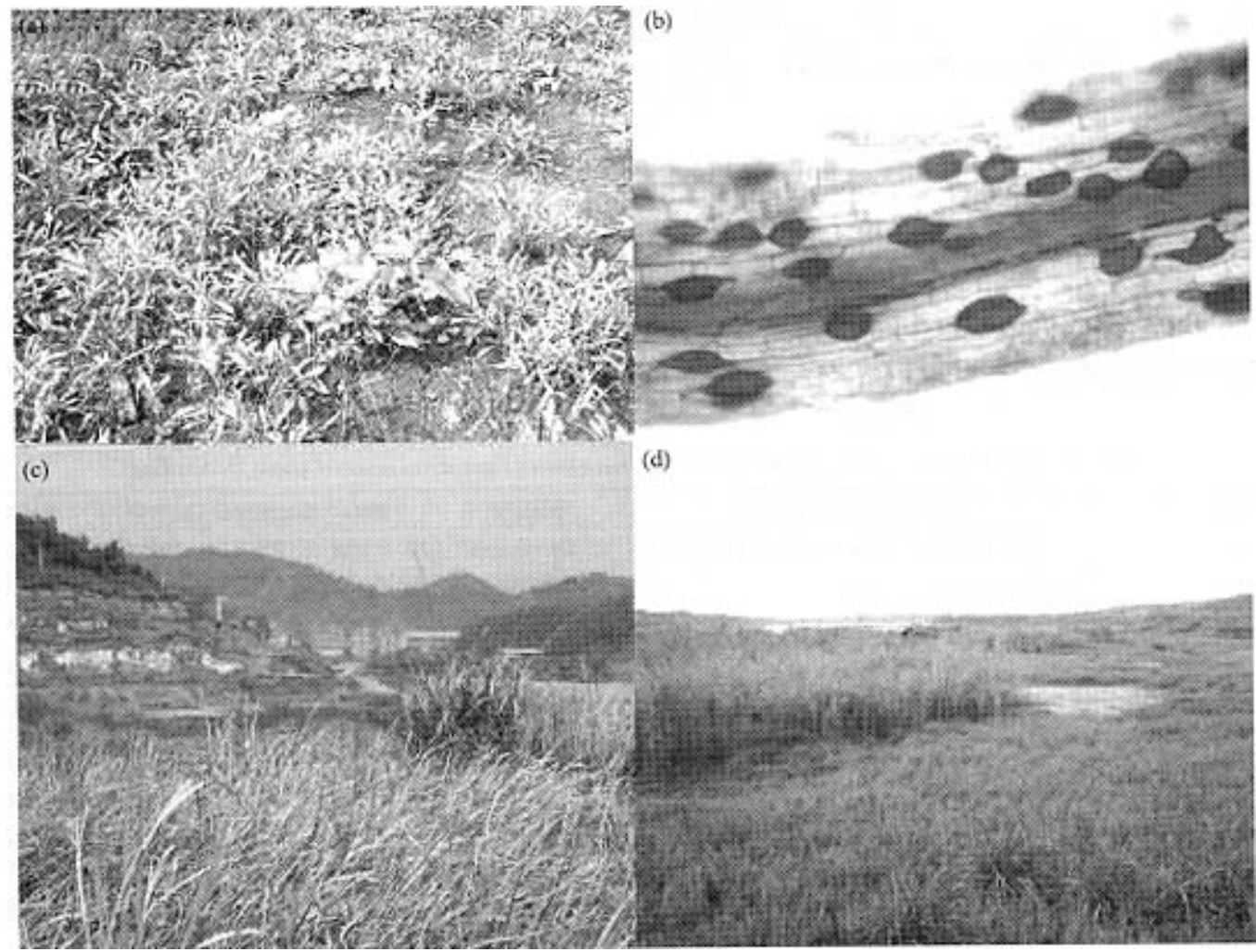

Fig. 1. Photographs of the vegetation on copper mine tailings in Tongling, Anhui, China. (a) Community of Coreopsis drummondii on Yangshulin tailing; (b) mycorrhizal symbiosis of Coreopsis drummondii as revealed by fuchsin-acid staining; (c) Tongguanshan tailing; (d) Heishahe tailing.

Table 3 Elemental concentrations in dominant plant species

\begin{tabular}{|c|c|c|c|c|c|c|c|c|}
\hline Sampling site ${ }^{a)}$ & Plant species & Component & $\mathrm{P} / \mathrm{mg} \mathrm{g}^{-1}$ & $\mathrm{Cu} / \mu \mathrm{g} \mathrm{g}^{-1}$ & $\mathrm{Zn} / \mu \mathrm{g} \mathrm{g}^{-1}$ & $\mathrm{~Pb} / \mu \mathrm{g} \mathrm{g}^{-1}$ & $\mathrm{Cd} / \mathrm{\mu g} \mathrm{g}^{-1}$ & $\mathrm{As} / \mu \mathrm{g} \mathrm{g}^{-1}$ \\
\hline \multirow[t]{2}{*}{ Yangshulin } & Imperata cylindrica & Leaves & 0.42 & 39.4 & 23.3 & 8.18 & 0.18 & 3.78 \\
\hline & & Stems and roots & 0.45 & 49.7 & 22.0 & 2.95 & 0.22 & 2.02 \\
\hline \multirow[t]{2}{*}{ Yangshulin } & Cynodon dactylon & Shoots & 0.46 & 82.0 & 57.0 & 22.2 & 0.97 & 6.71 \\
\hline & & Roots & 0.13 & 105 & 47.1 & 3.13 & 0.39 & 4.56 \\
\hline \multirow[t]{2}{*}{ Yangshulin } & Setaria viridis. & Shoots & 0.72 & 41.3 & 112 & 7.6 & 0.96 & 2.50 \\
\hline & & Roots & 0.55 & 134 & 130 & 9.81 & 1.30 & 4.22 \\
\hline Yangshulin & Coreopsis drummondii & Roots & 0.55 & 304 & 70.1 & 18.0 & 1.93 & 6.25 \\
\hline \multirow[t]{2}{*}{ Fenghuangshan } & Pteris cretica & Fronds & 0.23 & 59.5 & 50.1 & 10.8 & 0.26 & 25.9 \\
\hline & & Roots & 1.02 & 235 & 320 & 118 & 3.38 & 83.5 \\
\hline Fenghuangshan & Pteris vittata & Fronds & 1.85 & 33.1 & 38.9 & 8.42 & 0.23 & 367 \\
\hline \multirow[t]{2}{*}{ Tongguanshan } & Imperata cylindrica & Leaves & 0.20 & 18.9 & 41.7 & 30.4 & 0.80 & 9.50 \\
\hline & & Stems and roots & 0.23 & 65.4 & 43.2 & 5.80 & 0.13 & 8.63 \\
\hline \multirow[t]{2}{*}{ Heishahe } & Paspalum distichum & Shoots & 0.82 & 41.0 & 80.0 & 7.52 & 0.85 & 17.0 \\
\hline & & Roots & 0.42 & 827 & 1522 & 63.3 & 12.5 & 96.5 \\
\hline
\end{tabular}


tailings, concentrations of these two elements in plant samples were generally low. The Chinese Brake fern accumulated very high concentrations of As in the fronds. In addition, Pteris cretica from Fenghuangshan had higher concentrations of $\mathrm{Cd}$ and $\mathrm{As}$ in the roots than to other plant species.

2.4 Transfer factors of heavy metals from soil to plants and metal partitioning in plants

With the sole exception of $\mathrm{Zn}$ in S. viridis from Yangshulin, the metal concentrations found in plant shoots were generally lower than those in tailings, as indicated by the TF values being mostly lower than 1 (Fig. 2). TF values for $\mathrm{Cu}$ were lower than 0.1 in all cases. For other metals the TF values varied between plant species and sampling sites. C. dactylon and $S$. viridis from Yangshulin showed higher TF values for
$\mathrm{Zn}$ and $\mathrm{Cd}$. The former also had high TF for $\mathrm{Pb}$. I cylindrica from Tongguanshan had relatively high TF values for both $\mathrm{Zn}$ and $\mathrm{Pb}$. P. cretica from Fenghuangshan showed higher TF values for As than other plant species.

In $S$. viridis from Yangshulin, $P$. distichum from Heishahe and $P$. cretica from Fenghuangshan, shootto-root ratios of metal concentrations were generally lower than 0.5 , indicating that most of the metals had been retained in the roots. In other plant samples, the shoot-to-root ratios of $\mathrm{Cu}$ concentrations were lower than 1 , and for As the ratios ranged from 1 to 2 , while for $\mathrm{Zn}$ the ratios were close to 1 . It was noticeable that $\mathrm{Pb}$ concentrations in the shoots of $C$. dactylon from Yangshulin and I. cylindrica from Tongguanshan, and $\mathrm{Cd}$ concentrations in shoots of I. cylindrica, were 4-fold higher than those found in the roots (Fig. 3).

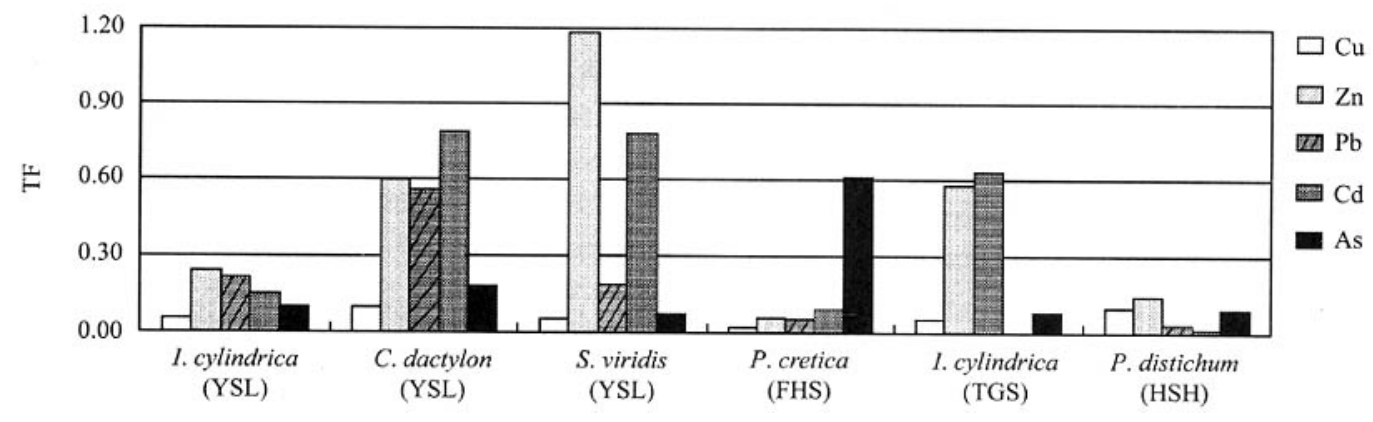

Plant species

Fig. 2. Transfer factors (TF) of metals from copper mine tailings to plants. YSL, Yangshulin; FHS, Fenghuangshan; TGS, Tongguanshan; HSH, Heishahe.

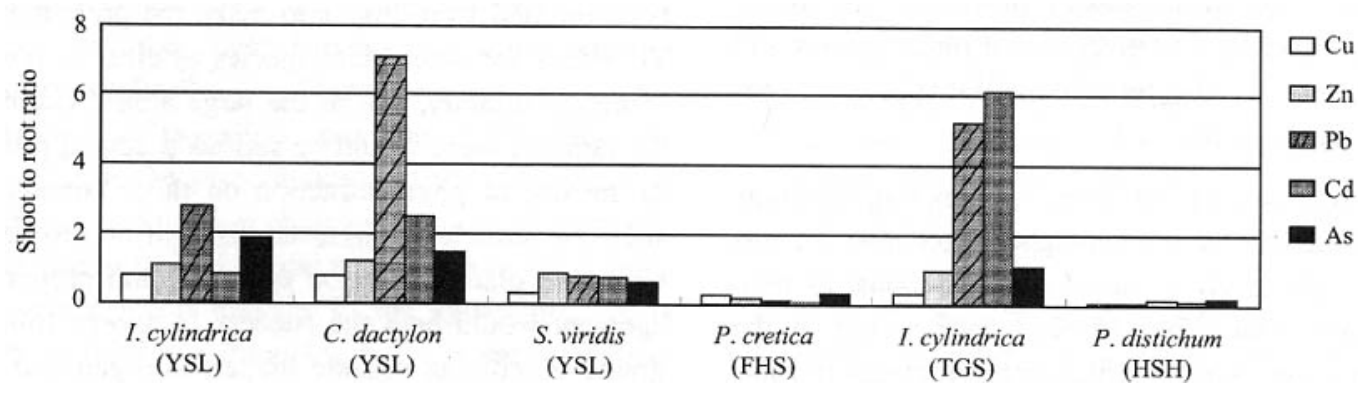

Plant species

Fig. 3. Shoot-to-root ratios of metal concentrations in dominant plants growing on copper mine tailings. YSL, Yangshulin; FHS, Fenghuangshan; TGS, Tongguanshan; HSH, Heishahe. 


\section{Discussion}

The field survey supports the hypothesis that native plants can be screened for revegetation of the mine tailings. Dominant plants growing on the mine tailings belong to the families Gramineae and Compositae, with the most widely distributed grasses Imperata cylindrical, Cynodon dactylon and Paspalum distichum. The relatively small numbers of plant species found clearly indicates that the tailings failed to support the growth of a diverse range of plant species. Only plants that adapted to the adverse environmental conditions can grow and establish communities without competition from other species. The dominant plants could be considered as likely candidates for future selection for the purposes of phytoremediation and revegetation programs.

The occurrence of mainly non-mycorrhizal plant species together with a smaller number of mycorrhizal plants growing on the tailings corresponds with the results of Gucwa-Przepiora and Turnau ${ }^{[26]}$ who conducted a survey of 69 vascular plant species colonizing an area of $\mathrm{Zn}$ wastes in Poland. They found that over $60 \%$ of the plant species were mycorrhizal, but two non-mycorrhizal species dominated the early successional stages of the $\mathrm{Zn}$ spoil where the only mycorrhizal species present showed no arbuscular development and the frequency of occurrence of individual AM species was highest in the oldest part of the area investigated. A strongly mycorrhizal plant species collected from the $\mathrm{Zn}$ wastes had abundant arbuscules except at the early establishment of the vegetation ${ }^{[27]}$. Colonization of metal wastes may therefore occur firstly by typically non-mycorrhizal plant species and then subsequently also by mycorrhizal species as ecological succession proceeds.

In most cases plant species colonizing the mine tailings have utilized the avoidance mechanism to survive the high levels of metal concentrations, as relatively low metal concentrations were found in the shoots or leaves but very high concentrations in roots (especially for $\mathrm{Cu}$ ). If the TF values are taken into consideration, it becomes clear that these plants function efficiently in preventing excessive metals from entering physiologically sensitive tissues. Paspalum distichum from Heishahe riverbed was a typical example. Shu et al. reported metal tolerant ecotypes of Paspalum distichum and the use of this tolerant population for revegetation of $\mathrm{Pb} / \mathrm{Zn}$ mine tailings ${ }^{[28,29]}$. Whether the population of Paspalum distichum found on Heishahe tailings has evolved tolerance to multi-metal contamination would require further investigation, but at least its potential use for revegetation has been indicated.

It is interesting to find highly significant correlations between $\mathrm{Cu}, \mathrm{Zn}$ and $\mathrm{Cd}$ concentrations in plants (correlation coefficients for $\mathrm{Cu}$ and $\mathrm{Zn}, \mathrm{Zn}$ and $\mathrm{Cd}$, and $\mathrm{Cu}$ and $\mathrm{Cd}$ are $0.943,0.950$ and 0.890 respectively, $n=16, P<0.001$ ). This may indicate some common resistance to multiple metal contaminations on the part of the dominant plants. On the other hand, Zhao et al. reported the hyperaccumulation potential for both $\mathrm{Zn}$ and $\mathrm{Cd}$ in Thlaspi caerulescens ${ }^{[30]}$. Although the mechanisms of synergistic resistance or tolerance to heavy metals by plants still await detailed studies, this may at least indicate the potential for phytoremediation of combined-metal contaminated environments.

Despite the fact that high metal concentrations were occasionally recorded in shoots of some plant species, they were all below the critical values for designation as hyperaccumulators (except for Pteris vittata, already identified by $\mathrm{Ma}$ et al. as an arsenic hyperaccumulator ${ }^{[31]}$ ). The TF value for As found in Pteris vittata from Fenghuangshan was 8.57 but has been omitted from Fig. 1 to make the presentation of TF values for other plant species as clear as possible. More importantly, due to the large areas occupied by the tailings, there would be serious practical problems in the use of phytoextraction on these contaminated sites. Nevertheless, phytostabilization or revegetation by native plants might be practical, and proper management would help the success in revegetation programs. Firstly, as organic matter, nitrogen and available phosphorus were generally very low, amending the tailings with organic fertilizer or biosolids may possibly improve the fertility of the tailings and 
stimulate plant growth ${ }^{[2]}$. Secondly, to maintain stability of established vegetation, a range of plant species can be introduced. More attention should be paid to legumes ${ }^{[3]}$, as these plants can fix $\mathrm{N}_{2}$ from the atmosphere. Thirdly, the importance of AM fungi needs to be taken into account to improve biodiversity of the ecosystem. It is not known whether the failure to establish mycorrhizal associations was one of the factors limiting diversity of colonizing plants, but the poor phosphorus nutrition of most plants may indicate a role of symbiotic associations.

Moreover, it should be noted that Imperata cylindrica tended to colonize the dry tailings, but not wet sites such as Heishahe. In contrast, Paspalum distichum grew better on the wet sites. Cynodon dactylon is the most widely distributed plant spices that grow well under drought stress, but it also shows better growth under moist conditions. This indicates the importance of moisture for supporting plant growth, and irrigation would help vegetation establishment on dry tailings, at least until the organic matter content of the substrate has increased for improved water retention. Otherwise, it is necessary to select plant species such as $I$. cylindrica or $C$. dactylon which may have already adapted to drought conditions for revegetation of the dry sites. In addition, it is interesting that Coreopsis drummondii survived and established communities on Yangshulin tailings. However, there is anecdotal evidence from local residents that this plant species is not naturally occurring one but a garden escape.

Negative effects of heavy metal contamination on mycorrhizal colonization and fungal growth have been observed in other field surveys and sometimes in laboratory studies ${ }^{[8,32,33]}$. Under extreme conditions, mycorrhizal colonization may be completely depressed $^{[34]}$. In the present field survey, the very low AM fungal colonization observed in most of the plants may be due to lack of fungal propagules in the tailings or to severe metal toxicity to the symbionts. $\mathrm{Cu}$ is commonly used as a fungicide and it is very effective. $\mathrm{Zn}$ - and Cd-tolerant AM fungal strains have already been isolated ${ }^{[11,14]}$, but there are no published reports on $\mathrm{Cu}$-tolerant strains. The extensive mycorrhizal colonization observed in the roots of $C$. drummondii and $C$. dactylon from the copper mine tailings indicates that these fungal strains may have evolved tolerance to $\mathrm{Cu}$ contamination (together with other metals), and may possibly be isolated and screened in the future.

In order to utilize native plants for future revegetation schemes, more detailed investigations should be conducted to improve our understanding of plant adaptation to mine tailings, to identify the potential role of arbuscular mycorrhiza in phytostabilizing metals in contaminated environments and in stimulating plant growth so that use can be made of both plant and fungal symbionts for successful revegetation. Our experiments in progress have shown that inoculation with an AM fungus did markedly enhance the growth of Trifolium repens (Leguminosae), Coreopsis drummondii (Compositae) and Pteris vittata (Pteridaceae), but not Lolium perenne (Gramineae), on the mine tailings collected from Yangshulin (data not presented). These results are exciting and will stimulate further work on isolation of metal tolerant fungal strains.

Acknowledgements The authors thank Dr Q.Y. Sun (Nanjing University) for assistance in identification of plant species. This work was supported by the National Natural Science Foundation of China (Grant No. 40401031), the 863 Program of the Chinese Ministry of Science and Technology (Projects Nos. 2001 AA645010-4 and 2002CB410808).

\section{References}

1. Chen, H. M., Zheng, C. R., Tu, C. et al., Heavy metals pollution in soils in China: status and countermeasures, Ambio., 1999, 28: 130.

2. Wong, M. H., Ecological restoration of mine degraded soils, with emphasis on metal contaminated soils, Chemosphere, 2003, 50: 775 .

3. Tordoff, G. M., Baker, A. J. M., Willis, A. J., Current approaches to the revegetation and reclamation of metalliferous mine wastes, Chemosphere, 2000, 41: 219.

4. van der Heijden, M. G. A., Klironomos, J. N., Ursic, M. et al., Mycorrhizal fungal diversity determines plant biodiversity, ecosystem variability and productivity, Nature, 1998, 396: 69.

5. Genney, D. R., Hartley, S. H., Alexander, I. J., Arbuscular mycorrhizal colonization increases with host density in a heathland community, New Phytol., 2001, 152: 355

6. Leyval, C., Turnau, K., Haselwandter, K., Effect of heavy metal pollution on mycorrhizal colonization and function: Physiological, ecological and applied aspects, Mycorrhiza, 1997, 7: 139.

7. Haselwandter, K., Bowen, G. D., Mycorrhizal relations in trees for agroforestry and land rehabilitation, For. Ecol. Manage., 1996, 81: 1.

8. Pawlowska, T. E., Blaszkowski, J., Ruhling, A., The mycorrhizal 
status of plants colonizing a calamine spoil mound in southem Poland, Mycorrhiza, 1996, 6: 499.

9. Shetty, K. G., Banks, M. K., Hetrick, B. A. D. et al., Biological characterization of a southeast Kansas mining site, Water Air Soil Pollut., 1994, 78: 169.

10. Shetty, K. G., Hetrick, B. A. D., Figge, D. A. H. et al., Effects of mycorrhizae and other soil microbes on revegetation of heavy metal contaminated mine spoil. Environ. Pollut., 1994, 86: 181.

11. Griffioen, W. A. J., Characterization of a heavy metal-tolerant endomycorrhizal fungus from the surroundings of a zinc refinery, Mycorrhiza, 1994, 4: 197.

12. Hildebrandt, U., Kaldorf, M., Bothe, H., The zinc violet and its colonization by arbuscular mycorrhizal fungi, J. Plant Physiol., 1999, 154: 709

13. Raman, N., Nagarajan, N., Gopinathan, S. et al., Mycorrhizal status of plant species colonizing a magnesite mine spoil in India, Biol. Fertil. Soils, 1993, 16: 76.

14. Weissenhorn, I., Leyval, C., Berthelin, J., Cd-tolerant arbuscular mycorrhizal (AM) fungi from heavy metal polluted soil, Plant Soil, 1993, 157: 247.

15. Weissenhorn, I., Glashoff, A., Leyval, C. et al., Differential tolerance to $\mathrm{Cd}$ and $\mathrm{Zn}$ of arbuscular mycorrhizal (AM) fungal spores isolated from heavy metal polluted and unpolluted soils, Plant Soil, 1994, 167: 189.

16. Vangronsveld, J., Colpaert, J. V., Van Tichelen, K. K., Reclamation of a bare industrial area contaminated by non-ferrous metals: Physico-chemical and biological evaluation of the durability of soil treatment and revegetation, Environ. Pollut., 1996, 94: 131.

17. Khan, A.G., Kuek, C., Chaudhry, T.M. et al., Role of plants, mycorhizae and phytochelators in heavy metal contaminated land remediation, Chemosphere, 2000, 41: 197.

18. Leyval, C., Joner, E. J., del Val, C. et al., Potential of arbuscular mycorrhizal fungi for bioremediation. In: Gianinazzi, S., Schüepp, H., Barea, J. M. et al., Mycorrhizal technology in agriculture, Basel, Switzerland: Birkhäuser Verlag, 2002, 175-186.

19. Wang, Z. Y., Sun, Q. Y., Lu, Y. C., Rehabilitation of biotic community of copper mine tailings in Tongling copper mine, Chinese J. Ecol. (In Chinese), 2000, 19(3): 7.

20. Olsen, S. R., Cole, C. V., Watanabe, F. S. et al., Estimation of available phosphorus in soils by extraction with sodium bicarbonate, USDA Agric. Circ., 1954, 939: 1.

21. Murphy, J., Riley, J. P., A modified single solution method for the determination of phosphate in natural waters, Anal Chim. Acta., 1962, 27: 31 .
22. Sun, D. H., Waters, J. K., Mawhinney, T. P., Determination of thirteen common elements in food samples by inductively coupled plasma atomic emission spectrometry: Comparison of five digestion methods, J AOAC Int., 2000, 83: 1218.

23. Sahrawat, K. L., Kumar, G. R., Rao, J. K., Evaluation of triacid and dry ashing procedures for determining potassium, calcium, magnesium, iron, zinc, manganese, and copper in plant materials, Comm. Soil Sci. Plant Anal., 2002, 33: 95.

24. Phillips, J. M., Hayman, D. S., Improved procedures for clearing and staining parasitic and vesicular-arbuscular mycorrhizal fungi for rapid assessment of infection, Trans. Br. Mycol. Soc., 1970, 55: 158.

25. Giovannetti, M., Mosse, B., An evaluation of techniques for measuring vesicular- arbuscular mycorrhizal infection in roots. New Phytol., 1980, 84P: 489.

26. Gucwa-Przepiora, E., Turnau, K., Arbuscular mycorrhiza and plant succession on zinc smelter spoil heap in Katowice-Welnoviec, Acta Soc. Bot. Poloniae, 2001, 70; 153.

27. Turnau, K., Heavy metal content and localization in mycorrhizal Euphorbia cyparissias from zinc wastes in southern Poland, Acta Soc. Bot. Poloniae, 1998, 67: 105.

28. Shu, W. S., Zhang, Z. Q., Huang, L. N. et al., $\mathrm{Pb}, \mathrm{Zn}$ and $\mathrm{Cu}$ tolerance and accumulation in populations of Paspalum distichum, Acta Sci. Nat. Uni. Sun., 2000, 39(4): 82.

29. Shu, W. S., Zhang, Z. Q., Huang, L. N. et al., Use of tolerant population of $P$. distichum for revegetation of a $\mathrm{Pb} / \mathrm{Zn}$ mine tailings at Lechang: Field experiment, Acta Sci. Nat. Uni. Sun., 2000, 39(4): 94

30. Zhao, F. J., McGrath, S. P., Assessing the potential for zinc and cadmium phytoremediation with the hyperaccumulator Thlaspi caerulescens, Plant Soil, 2003, 249: 37.

31. Ma, L. Q., Komar, K. M., Tu, C. et al, A fern that hyperaccumulates arsenic, Nature, 2001, 409: 579.

32. Liu, A., Hamel, C., Hamilton, R. I. et al., Acquisition of $\mathrm{Cu}, \mathrm{Zn}$, $\mathrm{Mn}$ and Fe by mycorrhizal maize (Zea mays L.) grown in soil at different $P$ and micronutrient levels, Mycorrhiza, 2000, 9: 331.

33. Bi, Y. L., Li, X. L., Christie, P., Influence of early stages of arbuscular mycorrhiza on uptake of zinc and phosphorus by red clover from a low-phosphorus soil amended with zinc and phosphorus, Chemosphere, 2003, 50: 831.

34. Gildon, A., Tinker P. B., Interactions of vesicular-arbuscular mycorrhizal infection and heavy metals in plants $I$. The effects of heavy metals on the development of vesicular-arbuscular mycorrhizas, New Phytol., 1983, 95: 247. 